http://jpps.ukaazpublications.com
DOI: http://dx.doi.org/10.21276/jpps.2021.1.1.4
Journal of Phytonanotechnology and Pharmaceutical Sciences

Orginal article: Open access

\title{
Phytonanotechnological perspectives and biological activities in Curcuma species
}

\author{
Mohammed Abdul Rasheed Naikodi ${ }^{\star}$, Dandu Chaithra, Baira Venkatesham, Javed Inam Siddiqui and Munawwar Husain Kazmi \\ *Drug Standardization Research Unit, National Research Institute of Unani Medicine for Skin Disorders, A.G. Colony Road, Erragadda, \\ Hyderabad-500038, Telangana State, India
}

\section{Article Info}

\section{Article history}

Received 7 January 2021

Revised 9 February 2021

Accepted 11 February 2021

Published online 30 March 2021

\section{Keywords}

Phytonanotechnology

Curcuma species

Biological activities

\begin{abstract}
Natural resources are always been an essential and invaluable source for the novel chemical entities having therapeutic activities. The structural changes in the chemical compounds are mainly responsible for the vast pharmacological and other biological properties. The upsurge need for the more effective and highly potent drugs for various agents such as antimicrobial, antidiabetic, anticancer, antidiarrhoeal, anti-inflammatory, antiarthritic, etc. Plant based nanotechnology driven drugs, phytonanotechnology materials have been developed and integrated into different applications such as industrial, biomedical and agricultural for better usage in the disease prevention, treatment and management having good efficacy. The utility of these plant based nanomaterials due to their unusual characteristics may resolve several challenges in the drug delivery and exhibit various pharmacological and biological activities. The synthesis by physical and chemical methods are expensive and unsafe, therefore, green synthesis of nanoparticles to be utilized with the aid of medicinal plants, bacteria, fungi which are novel ecofriendly techniques. Zingiberaceae family comprises about 50 genera usually found throughout the warm regions of both the hemispheres. The Curcuma species characterize by the presence of curcuminoids, turmerones, volatile oils and oleoresins of export value. Curcuma species has acquired great importance all over the world due to wide medicinal activities such as antimicrobial, antiulcer, antidiarrhoeal, antiaging, antialzheimer, antioxidant, antidiabetic, anti-inflammatory. Various species of Curcuma has been extensively reported for their pharmacological activity. These species are effective against several diseases and also in remedies used by tribal.
\end{abstract}

\section{Introduction}

Currently applications in the usage of plant based nanotechnology systems such as phytonanotechnology has gained importance. It allows target-site specific drug delivery through phytonanomaterials to agricultural fields and other plants. This causes enhanced functions of plants and environment friendly and resistance to pollution.

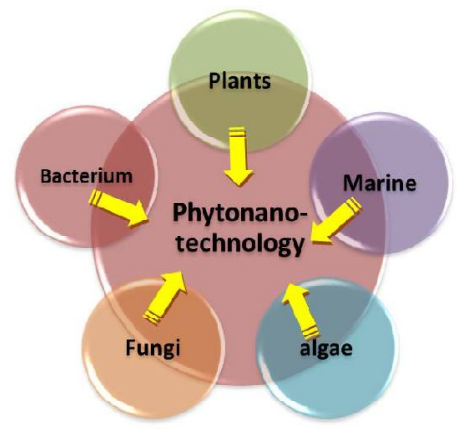

Figure 1: Sources of phytonanotechnology.

Corresponding author: Dr. Mohammed Abdul Rasheed Naikodi
Scientist, Drug Standardization Research Unit, National Research
Institute of Unani Medicine for Skin Disorders, A.G. Colony Road,
Erragadda, Hyderabad-500038, Telangana State, India
E-mail: rasheed.crium @gmail.com
Tel.: +91-9959840785

Copyright $\odot 2021$ Ukaaz Publications. All rights reserved.

Email: ukaaz@yahoo.com; Website: www.ukaazpublications.com
Phytonanotechnology has influenced scientific fraternity to do more studies in this direction. Phytonanotechnology products can be obtained from different resources such as plants, bacterium, marine, fungi, algae, etc., as depicted in Figure 1 which sources yields variety of products illustrated in Figure 2 ( $\mathrm{Li}$ and Yan, 2020).

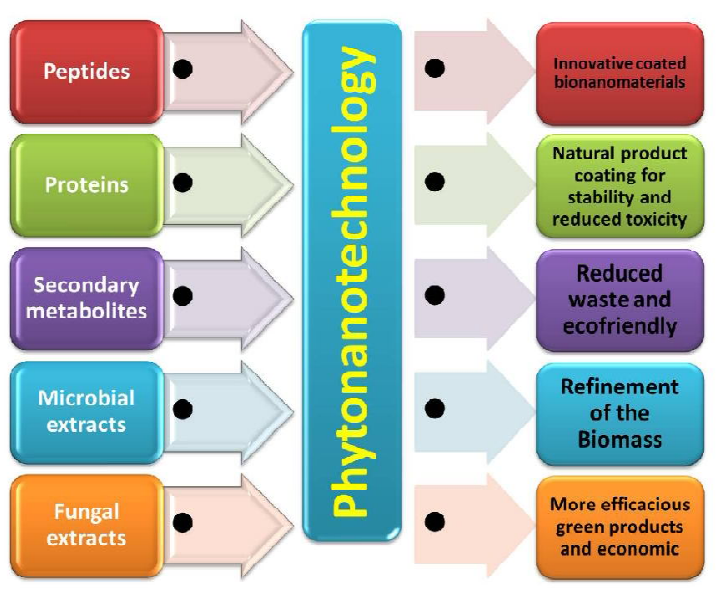

Figure 2: Phytonanotechnology sources yields variety of products. Phytonanotechnology has also become popular in the field of nanofertilizers, nanoinsecticides and nanopesticides due to the inherent benefits and nanoscale size effects which are capable of better uptake of minerals, insecticides and pesticides by the plants. 
(Chhipa, 2017; Kah et al., 2018). Nanotechnology has been used in case of turmeric to produce more efficacy in the phytonanomaterials products from different Curcuma species particularly in Curcuma longa $\mathrm{L}$. Turmeric is very important spice in India which produces nearly $80 \%$ of the whole world's consumption and largest producer and exporter of turmeric under spices and condiments. Several species of Curcuma are native to India, Curcuma longa (Watt, 1872) among one of them. Rhizome of turmeric (Curcuma longa) contains a potent polyphenol compound curcumin (Rasheed et al., 2017) which possess potent anticancer properties showed in plethora of human cancer cell line and animal carcinogenesis models. The clinical application of curcumin efficacious agent in cancer and other diseases has been reduced due to its poor aqueous solubility, and minimal systemic bioavailability. Nanoparticle-based drug delivery approaches for rendering hydrophobic agents like curcumin dispersible in aqueous media, thus avoiding the drawbacks of poor solubility.Thus, nanotechnology enhances the potential properties of turmeric and increases the possibilities for the application of its components.

Curcuminoids are one of the important bioactive secondary metabolite present in Curcuma species which prevents the spoilage of fat foods during storage (Revarkar and Sen, 1975). And also used in the preparation of pickles (Govindarajan and Stahl, 1980). $C$. longa essential oils are used in the perfumery, cosmetics and soap industry (Ramachandraiah et al., 1998). The food regulation Act 1996, part III schedule-5 confirms the usage of curcumin in various items in U.K. (Henry, 1998). Anticancerous drug dose level of curcumin ranges from 5-200 ppm (Chen and Huang, 1998). Chemo protective role of curcumin in human colon cancer was studied (Kawamori et al., 1999). Essential oil of turmeric is found to be effective in ayurvedic medicine of Indian system (Marwah and Shetty, 2000). In food industry, turmeric powder is used in Asian countries for making vegetables and meat preparations (Sasikumar, 2005). C.longa is the major source of curcuminoids and volatile oils (Jayaprakasha et al., 2002). Curcumin also inhibits Sperm motility and acts as novel intravaginal contraceptive (Rithaporn et al., 2003), antidiabetic activities (Suryanarayana et al., 2003). The crude form of turmeric powder, fresh ground turmeric and the water, ether, chloroform and methanolic extracts plays an important role in the bioprotective activity of various ailments. Curcuma longa consists $3-8 \%$ of curcuminoids as a major content than in other species (Varghese, 1999).
Out of 10 Curcuma species, Curcuma amada and Curcuma zedoaria are distributed throughout India in the wild and in cultivation whereas the four species $C$. aeruginosa, $C$. brog, $C$. caesia and $C$. sylvatica distributed only in wild conditions along northeastern parts of India. C. malabarica and $C$. aromatica distributed in South India while C. rakthakanta and $C$. harita are distributed throughout Kerala (Velayudhan et al., 1999). Curcuma neilgherrensis is reported from Andhra Pradesh from araku valley and seshachalam hill ranges of tirumala and talakona along the eastern ghats (Pullaiah, 1997). Turmeric has been used as medicine and coloring agent. It acts as effective in wound healing and also against stomach ache, flatulence, poisonous reptile bites, ulcers, common cold, pimples and bronchitis, anti-inflammatory, antidiabetic, sinusitis, etc. (Sasikumar, 2005).

In the traditional veterinary medicine, also Curcuma plays an important role on the rural poultry and to treat skin diseases of camel and buffalo (Chhabra et al., 1994), mastitis in cattle (Joshi et al., 1996). C. aromatica extracts against cattle anti-inflammatory activity (Jangde et al., 1998). Turmeric poultice is applied on broken legs of chicken and domestic animals (Mandal and Chauhan, 2000); also used to cure raniket disease of birds, prevent hair fall, scabies, heal cuts and wounds ring worm infection, itching, eczema, boils, urticaria and chronic skin eruptions of domestic animals (Sharma and Joshi, 2004).

Curcumanol compound yielded from hydroalcoholic extract of C.zedoaria is proved to use as analgesic (Navarro et al., 2002). C. caesia, $C$. amada and C. longa rhizome consist four secondary metabolites only (Jose and Thomas, 2014; Donipati and Sreeramulu, 2015; Pawar et al., 2015). In recent studies, oil extraction from the C.longa leaves yielded terpenoids compound which also used as biofuels an alternative to that of petrol (Gantait et al., 2011).

Macro and microscopic studies of $C$. neilgherrensis reveals that the rhizome in conical shape, brownish with mild aromatic flavor to that of C.caesia. But, it is different from other Curcuma species in having fusiform long tuberous roots, with secondary branching. Saponins are present only in $C$. neilgherrensis whereas in other Curcuma species they are absent. Hence, each Curcuma species is having specific pharmacognostic characters to be identified in its quality and quantity in the drug formulations and also to check the adulterations (Chitra and Thoppil, 2002; Shyam et al., 2013; Prakash et al., 2011).

\subsection{Ethnomedicinal uses of Curcuma species}

Table 1: Ethnomedicinal uses in different part of the Curcuma species and their medicinal properties

\begin{tabular}{|l|l|l|l|}
\hline Plant name & \multicolumn{1}{|c|}{ Medicinal uses } & Part used & Reference \\
\hline Curcuma amada & $\begin{array}{l}\text { Anti-inflammatory, bruises, sprains, wounds, } \\
\text { skin diseases, bronchitis, asthma, diarrhoea; } \\
\text { Antimicrobial and antioxidant; CNS Depressant } \\
\text { and analgesic activity; Antiallergic, Brine- } \\
\text { shrimp lethal; Platelet aggregation inhibitory, } \\
\text { Cytotoxicity; Hypoglycemic; } \\
\text { Anti-hyperglycemic }\end{array}$ & Rhizomes & $\begin{array}{l}\text { Mujumdar } \text { et al., 2000; } \\
\text { Joy et al., 2001; Ankli et al., 2002; } \\
\text { Mujumdar } \text { et al., 2004; } \\
\text { Krishnaraju } \text { et al., 2006; } \\
\text { Policegoudra and Aradya, 2008; } \\
\text { Syiem et al., 2010 }\end{array}$ \\
\hline Curcuma aromatica & $\begin{array}{l}\text { Antitumor, antidementia, bruises, sprains, } \\
\text { bronchitis, cough and skin eruptions, } \\
\text { antiallergy }\end{array}$ & Rhizomes & $\begin{array}{l}\text { Ozaki., 1990; Khar } \text { et al., 1999; } \\
\text { Lim } \text { et al., 2001; Joy et al., 2001; } \\
\text { Ram } \text { et al., 2003 }\end{array}$ \\
\hline
\end{tabular}




\begin{tabular}{|c|c|c|c|}
\hline $\begin{array}{l}\text { Curcuma aromatica } \\
\text { Curcuma amada } \\
\text { Curcuma zedoaria }\end{array}$ & Intestinal worms & Rhizomes & Joy et al., 2001 \\
\hline $\begin{array}{l}\text { Curcuma amada } \\
\text { and Curcuma caesia }\end{array}$ & Anti-inflammatory, antimicrobial & Rhizomes & Gill et al., 2011 \\
\hline $\begin{array}{l}\text { Curcuma aeruginosa, } \\
\text { C. brog } \\
\text { C. malabarica } \\
\text { C. rakthakantha } \\
\text { C. sylvatica }\end{array}$ & Antioxidant & Leaves & Angel et al., 2012 \\
\hline Curcuma aeruginosa & $\begin{array}{l}\text { Antinociceptive, antipyretic and anti-inflammatory, } \\
\text { cough, asthma, rheumatic conditions }\end{array}$ & Rhizomes & $\begin{array}{l}\text { Reanmongkol et al., 2006; } \\
\text { Nasrullah et al., } 2010\end{array}$ \\
\hline Curcuma angustifolia & $\begin{array}{l}\text { Leprosy, asthma, anemia and leukoderma, pneumonia, } \\
\text { cough, asthma }\end{array}$ & Rhizomes & $\begin{array}{l}\text { Kirtikar and Basu, 1987; } \\
\text { Chourasia, } 2006\end{array}$ \\
\hline Curcuma caesia & Sprains and bruises, snake and scorpion bites & Rhizomes & Tag et al., 2007 \\
\hline $\begin{array}{l}\text { Curcuma longa }+ \\
\text { Zingiber officinale }\end{array}$ & Analgesic, antibacterial, antioxidant, expectorant & Rhizomes & Mujumdar et al., 2000 \\
\hline Curcuma longa & Hypoglycemic, hypolipidemic and antioxidant & $\begin{array}{l}\text { Rhizomes, } \\
\text { Whole plant }\end{array}$ & Hussain, 2002 \\
\hline $\begin{array}{l}\text { Curcuma longa and } \\
\text { Zingiber officinale }\end{array}$ & Analgesic, antibacterial, antioxidant, expectorant & Rhizomes & Singh et al., 2011 \\
\hline $\begin{array}{l}\text { Curcuma longa, } \\
\text { Zingiber officinalis, } \\
\text { Zingiber zerumbet }\end{array}$ & Anthelmintic & Rhizomes & Raul et al., 2012 \\
\hline Curcuma longa & $\begin{array}{l}\text { Anti-inflammatory, hepatoprotective, antimicrobial, } \\
\text { wound healing anticancer, antitumour and antiviral, } \\
\text { antiulcer, antimicrobial, anti-inflammatory }\end{array}$ & Rhizomes & $\begin{array}{l}\text { Ross, 1999; Ghongane and } \\
\text { Rahul, 2011; Khan et al., } 2013\end{array}$ \\
\hline $\begin{array}{l}\text { Curcuma } \\
\text { neilgherrensis }\end{array}$ & $\begin{array}{l}\text { Skin diseases, throat infections, sneezing, } \\
\text { respiratory disorders, asthma }\end{array}$ & Flowers & $\begin{array}{l}\text { Kirtikar and Basu, 1935; } \\
\text { Rathnam and Raju, } 2005\end{array}$ \\
\hline $\begin{array}{l}\text { Curcuma } \\
\text { rakthakantha }\end{array}$ & $\begin{array}{l}\text { Diarrhoea, antidiabetic, antihyperglycemic and } \\
\text { antioxidant activity }\end{array}$ & Rhizomes & Inthirakanthi et al., 2013 \\
\hline Curcuma xanthorrhiza & $\begin{array}{l}\text { Liver disorders, constipation, bloody diarrhoea, } \\
\text { dysentery, haemorrhoids, skin eruptions; } \\
\text { antidiabetic activity }\end{array}$ & $\begin{array}{l}\text { Rhizomes } \\
\text { Leaf }\end{array}$ & $\begin{array}{l}\text { Hwang et al., 2000; } \\
\text { Adnyana et al., } 2013\end{array}$ \\
\hline $\begin{array}{l}\text { Curcuma xanthorrhiza } \\
\text { and Curcuma domestica }\end{array}$ & Antioxidant, anti-inflammatory & Rhizomes & Waras et al., 2012 \\
\hline
\end{tabular}

\subsection{Antimicrobial activity}

Studies on antibacterial activity for nanoparticles of C. longa, C. zedoaria, and A. sativum extract on chronic respiratory disease (CRD) infected chicken by M. gallisepticum and Escherichia coli carried out in vivo. The morphology of turmeric, zedoary, and garlic extract nanoparticle was smooth surface and sphere shapes as shown in Figure 3 (Handharyani et al., 2020). In vivo studies of nanoparticle extract combination of turmeric, zedoary, and garlic showed improved in growth and performance of chicken with recovery in clinical and pathological changes of CRD complex infection.
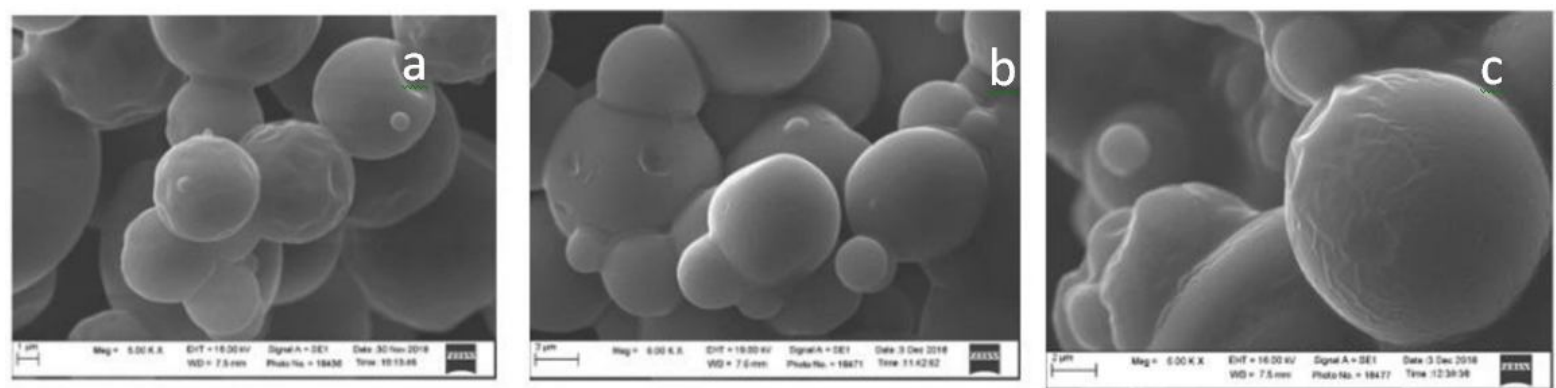

Figure 3: Morphology of nanoparticle under scanning electron microscope (SEM) analysis of (a) turmeric, (b) zedoary, and (c) garlic (Photo Source: Handharyani, et al., 2020). 
An ecofriendly novel method for silver nanoparticle was synthesized using rhizome extract of Curcuma amada. The green synthesized silver nanoparticle showed excellent antimicrobial activity and considerable zone of inhibition against both gram-negative and grampositive bacteria and fungi (Khairunnisa, and Anjana, 2018). Rhizome extracts of $C$. neilgherrensis consists a good number of secondary metabolites like alkaloids, flavonoids, phenols, steroids, tannins, lignins, indoles, glycosides, carbohydrates, proteins, amino acids proved effective antibacterial activity with alcohol and aqueous extracts at $10 \mathrm{mg} / \mathrm{well}$ with MIC $0.078 \mathrm{mg}$ on Staphylococcus aureus and Bacillus subtilis, Escherichia coli, Pseudomonas aeruginosa are inhibited equally to that of standard drug ampicillin due to the presence of $p$-hydroxy benzoic acid, vanilic acid, scopoletin, pincarvone, 3 -carene, terpinol, $\alpha$-thujene, $\beta$-pipene and $\alpha$-amorphene compounds. Whereas, C. zedoaria and C. malabarica rhizome, hexane and acetone extracts in 1:1 ratio combination against six bacterial and two fungal strains exhibited effective activity than other extracts and C.malabarica is most efficient activity against S.aureus than C.zedoaria (Wilson et al., 2005). Rhizome methanolic and alcoholic extracts inhibit anti-methicillin-resistance Staphylococcus aureus as that of C.longa apart from other bacterial strains to that of C.longa, C.zedoaria and C.xanthorrhiza (Kim et al., 2005; Maryet al., 2012; Yasodamma et al., 2013).Curcuma neilgherrensis can be used to synthesize nanoparticles using green chemistry methods for various applications. The $\mathrm{ZnO}$ nanoparticles were synthesized using Curcuma neilgherrensis methanolic extract of leaf and found to possess alkaloids, flavonoids, steroids, phenols, tannin and carbohydrates which showed good antibacterial activity (Parthasarathy, 2017).

Antifungal activity on Staphylococcus aureus and Bacillus subtilis strains with methanolic and alcoholic extracts of leaf and rhizome of C.neilgherrensis proved most effective to that of the control drug nystatin and the MIC values on C.albicans ranges from 0.156 to $2.5 \mathrm{mg}$ and on A. niger ranges from 0.312 to $2.5 \mathrm{mg}$. The lowest concentrations observed with methanol and alcoholic extracts of both leaf and rhizome extracts at $0.156 \mathrm{mg}$ on $C$. albicans due to the presence of phytoconstituents sinapic acid, melilotic, cinnamic acids, pinocarvone and terpineolcompounds. Antifungal activity with isolated compounds of $C$. longa and $C$. xanthorrhiza, $C$. malabarica, $C$. zedoaria is equal to that of $C$. neilgherrensis crude extracts and volatile oils curcuminoids shows most promising activity (Singh and Jain, 2011; Wilson et al., 2005).

\subsection{Antiulcer activity}

Effective antiulcer activity was observed with aqueous rhizome extracts of C. neilgherrensis at $500 \mathrm{mg} / \mathrm{kg}$ with ulcer index and ulcer protection and also decreased levels of gastric juice, free and total acidity to that of the pyloric ligated ulcer induced rats and equal when compared to the standard drug, omeprazole treated rats. $\mathrm{pH}$ also maintained to that of normal rats. Qualitative analysis of phenols, flavonoids and anthocyanidins of $C$. neilgherrensis of various phytoconstituents which also helpful in regulating ulcer activity. Caffeic acid (leaf and rhizome) may protects the intestinal carcinogenic activity (Tonari et al., 2002; Yasodamma et al., 2014). Myricetin (leaf) plays an important role in the inhibition of tumors and lowers the risk of prostate and pancreatic cancer (Knekt et al., 2002). Apigenin (leaf) antitumorous (Si et al., 2009); kaempferol (leaf) strong antioxidant prevents formation of cancer cells as chemopreventive especially bone (Andlauer, 1998); tumour (Pang et al., 2006). Cyanidin (rhizome) has potent antioxidant activity and reduces the risk of leukaemia, colon, skin and prostate cancer (Sasaki et al., 2007). Antioxidant and anticancer activities of C.neilgherrensis methanolic leaf and rhizome extracts may show the cytoprotective effects in inhibiting the growth of MCF-7 (breast), Hela (cervical) and A-549 (lung) cancer cell lines (Rubalakshmi and Karmegam, 2011). C. longa ethanol extracts $500 \mathrm{mg} / \mathrm{kg}$; C. zedoaria root extracts at $200 \mathrm{mg} / \mathrm{kg}$, and also ethanolic extracts of $C$. caesia at $500 \mathrm{mg} / \mathrm{kg}$ (Das et al., 2012). Turmeric extracts possess highly significant antioxidant activity than $\alpha$-tocopherol. It is found that $\alpha$ - tocopherol can mitigate stress-induced ischemia in tissues (Toda et al., 1985).

\subsection{Antidiarrhoeal activity}

Methanolic rhizome extracts of C.neilgherrensis showed effective at $1000 \mathrm{mg} / \mathrm{kg}$ b.wt.for antidiarrhoeal activity may be due to the presence of a wide range of phytoconstituents like terpinoids, tannins, phloroglucinol and $m$-hydroxy benzoic acid, curcumol and caryophyllene compounds (Chaithra and Yasodamma, 2015). Castor oil produces diarrhoea due to its most active metabolite ricinoleic acid by hypersecretory response, which stimulates peristaltic activity in the small intestine, leading to changes in the electrolyte permeability of the intestinal mucosa. Castor oil also stimulates the release of endogenous prostaglandins $\mathrm{E}$ and $\mathrm{F}$ which cause stomach cramp and diarrhoea due to the effect on the smooth muscle and secretion (Saha and Paul, 2012). C.longa rhizome aqueous extract showed effective at $200 \mathrm{mg} / \mathrm{kg}$ b.wt. on both gastrointestinal motility and experimentally induced diarrhoea in mice (Owolabi $e t$ al., 2012).

\subsection{Anti-inflammatory activity}

Anti-inflammatory activity of $C$. neilgherrensis rhizome methanolic extracts at $250 \mathrm{mg} / \mathrm{kg}$ b.wt. more effective against inflammation to that of the standard drug diclofenac at $100 \mathrm{mg} / \mathrm{kg} \mathrm{b}$.wt.due to the presence of caffeic acid, apigenin, quercetin, curcumin, eucalyptol and terpineol compounds. Rhizome and leaf extracts proved non-toxic to that of C.amada and C. longa also proved equally effective anti-inflammatory drugs (Sudharshan et al., 2010; Kaushik and Jalapure, 2011), whereas C.aeruginosa, C.aromatica are showed toxicity effects but antiinflammatory activity at sub-lethal doses. The presence of quercetin in C. neilgherrensis reduces inflammation and flavonoids presence showed the inhibitory action against various enzymes as protein kinase, protein tyrosine kinases and phospholipase A (Middleton, 1998).

C. longa anti-inflammatory activity may be due to the presence of curcumin and effective inhibition on phosphorlipase, lipoxygenase cycloxygenase, leukotrienes, thromboxane, prostaglandins, nitric oxide, collagenase, peroxidase, tumor necrosis factor (TNF) and interleukin -12 (IL-12). Curcuminoids are the major constituents of turmeric along with bis-demethoxy curcumin and demethoxy curcumin possess antioxidant, anti-inflammatory, antiviral and antifungal activities (Chainani et al., 2003).

\subsection{Antiarthritic activity}

Effective inhibition of arthritic effect with rhizome extracts of C.neilgherrensis against acetic acid induced analgesic and against complete freund's adjuvant (CFA) induced arthritis rats. Both aqueous and methanol crude extracts at $1000 \mathrm{mg} / \mathrm{kg}$ b.wt.showed 
effective results to that of the control rats and also with the standard drug diazepam and diclofenac treated rats. The rhizome crude extracts of $C$. neilgherrensis shows the presence of phytoconstituents like delphinidin, apigenin, quercetin, caffeic acid and essential oils like terpineol, $\alpha$-thujene, n-heptane, curcumol, eucalyptol, 3-carene and pinocarvone compounds acts as effective antiarthritic drugs (Yasodamma and Chaithra, 2016).

Antiarthritic activity also observed by the application of standard piroxicam gel was found to inhibit arthritic edema to an extent of $66.96 \%$. A profound anti-arthritic effect of C.long a curcuminoid extracts inhibit nuclear factor - kB (NF-kB) activation in rheumatoid arthritis rats, blocking multiple downstream signaling pathways critical to joint inflammation, including cyclo-oxygenase (COX) stimulated prostaglandin- $\mathrm{E}_{2}\left(\mathrm{PGE}_{2}\right.$ ) production (Funket al., 2010).

\subsection{Antidiabetic activity}

C. neilgherrensis antidiabetic activity as effective drug at the minimum dose levels of $250 \mathrm{mg} / \mathrm{kg}$ b.wt. of rhizome extracts as safe drug and no toxicity and there is no negative effects on body weights and behavioural aspects; without alteration of haematological and biochemical parameters equal to that of normal rats and the standard drug glibenclamide treated rats due to the presence of high quantities of phenols and flavonoid compounds like quercitin, cyanidin, hirsutin, petunidin, malvidin, and n-heptane, $\alpha$-thujene compounds C.neilgherrensis rhizome may acts as potent drug in controlling the lipid peroxidation which regulates diabetic effect (Chaithra and Yasodamma, 2016). C. neilgherrensis is more effective than the $A$. galanga antidiabetic activity at $400 \mathrm{mg} / \mathrm{kg}$ b.wt.; C. longa + Abromine angusta at $300 \mathrm{mg} / \mathrm{kg}$ b.wt. C. raktakanta at $224.22 \mu \mathrm{g} /$ $\mathrm{ml}$ and $961.54 \mu \mathrm{g} / \mathrm{ml}$; C. xanthorrhiza + Gauzuma ulmifolia at 12.5 and $25 \mathrm{mg} / \mathrm{kg}$ b.wt., respectively (Adnyana et al., 2013). In $C$. angustifolia shows the presence of thujene, pipene, caryophyllene, amorphene and humulene 6-7 epoxide compounds (Nayaket al., 2014). Rhizomeethanolic extracts of $C$. raktakanthaalso revealed the presence of ethyl p-methoxycinnamate, $\alpha$-pinene, $\beta$-pinene, camphor, terpinyl acetate tumerone and some oleoresins. The antidiabetic and anti-hyperlipidemic activity shown by ECR might be due to the presence of polyphenols (Dan et al., 2002). Effects of C. longa on postprandial plasma glucose and insulin due to curcumin which inhibits nuclear factor-kappa B (NF- $\mathrm{KB}$ ) activation and protein carbonyl, lipid peroxidation, and lysosomal enzyme.The STZ induced diabetic rats showed significant increase in fasting blood glucose and decrease in body weight. The weight loss is due to increased muscle wasting and polyuria (Habibuddin et al., 2008).

\section{Conclusion}

Phytonanotechnology is a vital tool to advance more in our understanding of plant species fundamentally and modulate plant functional activities. In present paper, we have focused majorly on species, uses and applications of various phytoconstituents for diverse pharmacological and biological activities. Curcuma species are important medicinal plants with several lead molecules. Hence, isolation and identification of those important molecules are needed for opening of new window in therapeutics. Beneficial effects of turmeric are traditionally achieved through dietary consumption. An effective dose, safety and mechanism of action are required for the rational use of turmeric in the treatment of human diseases.
Curcuma species has revealed a large number of compounds, including curcumin, volatile oil and curcuminoids, turmerones which have been found to have potent pharmacological properties. The curcumin has multiple pharmacologic effects, but due to poor bioavailability therapeutic effects got suppressed which upon conjugating curcumin to metal oxide nanoparticles or encapsulation in lipid nanoparticles, dendrimers, nanogels and polymeric nanoparticles, thereby the water solubility or the bioavailability gets enhanced leading to increase its pharmacological properties. Similarly, further studies recommended for the other Curcuma species for different biological activities which includes antibacterial, antifungal, antiulcer, antidiarrhoeal, anti-inflammatory, antiarthritic, antioxidant and antidiabetic activities etc.

\section{Acknowledgements}

The authors are thankful to the Director General, CCRUM, New Delhi, and also Director, NRIUMSD, Hyderabad for providing necessary facilities.

\section{Conflict of interest}

The authors declare that there are no conflicts of interest relevant to this article.

\section{References}

Adnyana, I.K.; Yulinah, E.; Yuliet, and Kurniati, N.F.(2013). Antidiabetic activity of aqueous leaf extracts of Guazuma ulmifolia Lamk. ethanolic extracts of Curcuma xanthorrhiza and their combinations in alloxan-induced diabetic mice. Research Journal of Medicinal Plant, 7(3):158-164.

Andlauer, W. and Furst, P.(1998). Antioxidative power of phytochemicals with special reference to cereals. Cereal Foods World, 43:356-359.

Angel, G.R.; Vimala, B. and Nambisan, B.(2012). Phenolic content and antioxidant activity in five underutilized starchy Curcuma species. International Journal of Pharmacognosy and Phytochemical Research, 4(2):69-73.

Ankli, A.; Heinrich, M.; Bork, P.; Wolfram, L.; Bauerfeind, P.; Brun, R.; Schmid, C.; Weiss, C.; Bruggisser, J.; Gertsch, M.; Wasescha, M. and Sticher, O.(2002). Yucatee mayan medicinal plants: Evaluation based on indigenous uses. Journal of Ethnopharmacology, 79(1):43-52.

Chainani-Wu, N. (2003). Safety and anti-inflammatory activity of curcumin: A component of turmeric (Curcuma longa). The Journal of Alternative and Complementary Medicine, 9(1):161-168.

Chaithra, D. and Yasodamma, N. (2016). Antidiabetic activity of Curcuma neilgherrensis $\mathrm{Wt}$. rhizome extracts on alloxan induced diabetic albino rats. World Journal of Pharmaceutical Research, 5(4):657-679.

Chaithra, D.; Yasodamma, N. and Alekhya, C. (2015). Antidiarrhoeal activity of Curcuma neilgherrensis Wt. World Journal of Pharmacy and Pharmaceutical Sciences, 4(9):545-555.

Chen, H. and Huang, H.(1998). Effect of curcumin on cell cycle progression and apoptosis in vascular smooth cells. British Journal of Pharmacology, 124(6):1029-1040.

Chhabra, M.B.; Kumar, R. and Gupta, S.K. (1994). Efficacy of dermocept (herbal). cream against mange in camel and buffalo. Indian Veterinary Journal, 71(2):167-169.

Chhipa, H. (2017). Nanofertilizers and nanopesticides for agriculture, Environmental Chemistry Letters, 15:15-22.

Chitra, M. and Thoppil, J.E. (2002). Pharmacognostical and phytochemical studies on Curcuma amada (Linn.) rhizome (Zingiberaceae). Ancient Science of Life, 22(2):25-33 
Chourasia, V. (2006). Self-medication of Baiga tribal's, Aayushman. pp. 49.

Dan, M.; George, V. and Pushpagadan, P.(2002). Studies on the essential oils of Curcuma haritha Mangaly \& Sabu and C. raktakanta Mangaly \& Sabu. Journal of Spices and Aromatic Crops, 11(1):78-79.

Das, S.; Bordoloi, P.K.R.; Phukan, D. and Singh, S.R.(2012). Study of the Antiulcerogenic activity of the ethanolic extracts of rhizome of Curcuma caesia (EECC) against gastric ulcers in experimental animals. Asian Journal of Pharmaceutical and Clinical Research, 5(2):200-203.

Donipati, P. and Sreeramulu, H.(2015). Preliminary phytochemical screening of Curcuma caesia. International Journal of Current Microbiology and Applied Sciences, 4(11):30-34.

Funk, J.L.; Frye, J.B.; Oyarzo, J.N.; Zhang, H. and Thimmermann, B.N. (2010) Anti-arthritic effects and toxicity of the essential oils of Turmeric (Curcuma longa). Journal of Agricultural and Food Chemistry, $\mathbf{5 8}(2): 842-849$.

Gantait, A.; Barman, T. and Mukherjee, P.K.(2011). Validated method for estimation of curcumin in turmeric powder. Indian Journal of Traditional Knowledge, 10(2):247-250.

Ghongane, B.B. and Rahul, K. (2011). Evaluation of anti-ulcer activity of Curcuma longa in rats. Journal of Advances in Pharmacy and Healthcare Research,1(2):50-56

Gill, R., Vandna, K. and Singh, A.(2011). Phytochemical investigation and evaluation of anthelmintic activity of Curcuma amada and Curcuma caesia- A comparative study. Journal of Ethanopharmacology, 2(2):102-109.

Govindarajan, V.S. and Stahl, W.H. (1980). Turmeric-chemistry, technology and quality. CRC. Critical Reviews in Food Science and Nutrition, 12(2): 199-301.

Habibuddin, M.; Daghriri, H.A.; Humaira, T.; Al-Qahtani, M.S. and Hefzi, A.A.H.(2008). Antidiabetic effect of alcoholic extract of Curalluma sinaica L. on streptozotocin induced diabetic rabbits. Journal of Ethnopharmacology, 117(2):215-220.

Handharyani, E.; Sutardi, L.N.;Mustika, A.A. and Andriani, A. and Yuliani, S. (2020). Antibacterial activity of Curcuma longa (turmeric), Curcuma zedoaria (zedoary), and Allium sativum (garlic) nanoparticle extract on chicken with chronic respiratory disease Complex: In vivo Study. E3S Web of Conferences 151, 01054 doi.org/10.1051/e3sconf/202015101054.

Henry, B. (1998). Use of capsicum and turmeric as natural colors. Indian Spices, 35:7-14

Hussain, H.E.M.A. (2002). Hypoglycemic, hypolipidemic and antioxidan properties of combination of curcumin from Curcuma longa, Linn and partially purified product from Abroma augusta, Linn. in streptozotocin induced diabetes. Indian Journal of Clinical Biochemistry, 17(2):33-43.

Hwang, J.K.; Shim, J.S. and Pyun, Y.R. (2000). Antibacterial activity of xanthorrhizol from Curcuma xanthorrhiza against oral pathogens. Fitoterapia, 71(3):321-323.

Inthirakanthi, R.N.; Malathy, N. and Anusuya,N. (2013). Antidiabetic, antihyperlipidemic and antioxidant effect of ethanolic extract of Curcuma rakthakantha J.K. Mangaly and M. Sabu on streptozotozin induced diabetic rats. International Journal of Pharmacy and Pharmaceutical Sciences, 5(3):201-206.

Jangde, C.R.; Phadnaik, B.S. and Bisen, V.V. (1998). Anti-inflammatory activity of extracts of Curcuma aromatica salisb. Indian Veterinary Journal, 75(1):76-77.
Jayaprakasha, G.K.; Rao, L.J.M. and Sakariah, K.K.(2002). Improved HPLC method for the determination of curcumin, demethoxy curcumin and bisdemethoxy curcumin. Journal of Agricultural and Food Chemistry, 50(13):3668-3672.

Jose, S. and Thomas, T.D. (2014). Comparative phytochemical and antibacterial studies of two indigenous medicinal plants Curcuma caesia Roxb. andCurcuma aeruginosa Roxb. International Journal of Green Pharmacy, 8(1):65-71.

Joshi, H.C.; Kumar, M.; Saxena, M.J. and Chhabra, M.B. (1996). Herbal gel for the control of subclinical mastitis. Indian Journal of Dairy Science, 49(9):631-634.

Joy, P.P.; Thomas, J.; Mathew, S. and Skaria, B.P.(2001). Medicinal Plants. In: Bose, T.K., Kabir, J., Das, P. and Joy, P.P., Eds., Tropical Horticulture, Naya Prokash, Calcutta, pp. 449-632.

Kah, M.; Kookana, R.S.; Gogos, A. and Bucheli, T.D. (2018). A critical evaluation of nanopesticides and nanofertilizers against their conventional analogues. Nature Nanotechnology, 13(8):677-684.

Kaushik, M.L. and Jalapure, S.S. (2011). Anti-inflammatory efficacy of Curcuma zedoaria Rosc Root extracts. Asian Journal of Pharmaceutical and Clinical Research, 4(3):90-92.

Kawamori, T.; Lubet, R.; Steele, V.E.; Kelloff, G.J.; Kaskey, R.B.; Rao, C.V. and Reddy, B.S. (1999). Chemopreventive effect of curcumin-a naturally occurring anti-inûammatory agent during the promotion/ progression of stage of colon cancer. Cancer Research, 59(3):597-601.

Khairunnisa, C.M. and Anjana, M. (2018). Green synthesis and characterization of silver nanoparticles using Curcuma amada and evaluation of their antimicrobial activity. Journal of Pharmacy and Biological Sciences, 13(1):1-5.

Khan, M.B.; Rabby, M.A.; Ullah, M.H. and Hossain, C.F.(2013). Investigation of antimicrobial and anti-inflammatory activity of Curcuma longa. International Journal of Pharmaceutical Sciences and Research. 4(3):1105-1109.

Khar, A.; Ali, A.M.; Pardhasaradhi, B.V.V.; Begum, Z. and Anjum, R. (1999). Antitumor activity of curcumin is mediated through the induction of apoptosis in AK-5 tumor cells. FEBS Letters, 445(1):165-168.

Kim, D.; Lee, T.; Jang, T. and Kim, C.(2005). The inhibitory effect of a Korean herbal medicine, Zedoariae rhizoma, on growth of cultured human hepatic myofibroblast cells. Life Sciences, 77(8):890-906.

Kirtikar, K.R. and Basu, B.D.(1935). Indian medicinal plants, Vol. IV, $2^{\text {nd }}$ Edn, Periodical Experts Books Agency, Delhi. pp. 2423-2436.

Kirtikar, K.R. and Basu, R.D.(1987). Indian Medicinal Plants. Dehradun: International Book Distributors. pp. 2418-2426.

Knekt, P.; Kumpulainen, J. and Jarvinen, R.; Rissanen, H.; Heliövaara, M.; Reunanen, A.; Hakulinen, T.; Aromaa,A. (2002). Flavonoid intake and risk of chronic diseases. American Journal Clinical Nutrition, 76(3):560-568.

Krishnaraju, A.V.; Rao, T.V.N. and Sundararaju, D.(2006). Biological screening of medicinal plants collected from eastern ghats of India using Artemia salina (Brine Shrimp Test). International Journal of Applied Sciences and Engineering, 4(2):115-125.

Li, C. and Yan, B. (2020). Opportunities and challenges of phytonanotechnology. Environmental Science: Nano, 7(10):28632874. doi:10.1039/d0en00729c

Lim, G.P.; Chu, T.; Yang, F.; Beech, W.; Frautschy, S.A. and Cole, G.M.(2001). The curry spice curcumin reduces oxidative damage and amyloid pathology in an Alzheimer transgenic mouse. Journal of Neuroscience, 21(21):8370-8377. 
Mandal, M.K. and Chauhan, J.P.S.(2000). A survey of ethno veterinary medicine practices in West Bengal. Indian Journal of Veterinary Medicine, 20(2):90-91.

Marwah, J. and Shetty, S.N.(2000). Essential oil and aromatherapy in holistic healing. Indian Perfumer, 44(5):215-219.

Mary, H.P.; Susheela, G.K.; Jayasree. S.; Nizzy, A.M.; Rajagopal, B. and Jeeva, S.(2012). Phytochemical characterization and antimicrobial activity of Curcuma xanthorrhiza Roxb. Asian Pacific Journal of Tropical Biomedicine, 2(2):637-640.

Middleton, E.(1998). Effect of plant flavonoids on immune and inflammatory cell function. Advances in Experimental Medicine and Biology, 439:175-182.

Mujumdar, A.M.; Naik, D.G.; Dandge, C.N, and Puntambekar, H.M.(2000). Antiinflammatory activity of Curcuma amada Roxb. in albino rats. Indian Journal of Pharmacology, 32(6):375-377.

Mujumdar, A.M.; Naik, D.G; Misar, A.V.; Puntambekar, H.M. and Dandge, C.N.(2004). CNS depressant and analgesic activity of a fraction isolated from ethanol extract of Curcuma amada rhizomes. Pharmaceutical Biology, 42(7):542-546.

Nasrullah, I.; Murhandini, S. and Rahayu, W.P. (2010). Phytochemical study from Curcuma aeruginosa rhizome for standardizing traditional medicine extract. Journal of International Environmental Application and Science, 5(5):5-12.

Navarro, D.F.; Souza, M.M., Neto, R.A.; Golin, V.; Niero, R.; Yunes, R.A.; Monache, F.D. and Filho, V.C.(2002). Phytochemical analysis and analgesic properties of Curcuma zedoaria grown in Brazil. Phytomedicine, 9(5):427-32.

Nayak, S.; Jena, A.K.; Mittal, D.K. and Joshi, D.(2014). GC-MS analysis of phytoconstituents of some wild Zingiberaceae plants methanolic rhizome extracts. Research in Plant Sciences, 2(1):1-5.

Nurcholis, W.; Ambarsari, L.; Sari, N.L.P.E.K. and Darusman, L.K.(2012). Curcuminoid contents, antioxidant and anti-inflammatory activities of Curcuma xanthorrhiza Rox B. and Curcuma domestica Val. promising lines from Sukabumi of Indonesia. Prosiding Seminar Nasional Kimia Unesa. pp. 284-292.

Owolabi, O.J.; Arhewoh, M.I. and Aadum, E.J.(2012). Evaluation of the antidiarrhoeal activity of the aqueous rhizome extract of Curcuma longa. Journal of Pharmaceutical and Applied Sciences, 9(1):1-2

Ozaki, Y.(1990). Anti-inflammatory effect of Curcuma xanthorrhiza Roxb. and its active principles. Chemical and Pharmaceutical Bulletin, 38(4):1045-1048

Pang, J.L.; Ricupero, D.A.; Huang, S., Fatma, N., Singh, D.P.; Romero, J.R. and Chattopadhya, N.(2006). Differential activity of kaempferol and quercitin in attending tumor necrosis factor receptor family signaling in bone cells. Biochemical pharmacology, 71(6):818826

Parthasarathy, G.; Saroja, M. and Venkatachalam, M. (2017). Biosynthesis and GCMS analysis of Zinc Oxide nanoparticles from Leaf extract of Curcuma neilgherrensis Wight. International Journal of Advance Engineering and Research Development, 4(10):329-343.

Pawar, M.A.; Patil, S.S. and Nagrik, D.M. (2015). Phytochemical and physicochemical investigation of Curcuma longa Linn. rhizome. International Journal of Chemical and Physical Sciences, 4:458-463.

Policegoudra, R.S. and Aradya, S.M.(2008). Structure and biochemical properties of starch from an unconventional source-a mango ginger rhizome. Food Hydrocolloids, 22(4):513-519.
Prakash, R.O.; Kumar, R.K.; Rabinarayan, A. and Kumar, M.S.(2011). Pharmacognostical and phytochemical studies of Zingiber zerumbet (L.) rhizome. International Journal of Research in Ayurveda and Pharmacy, 2(3):698-703.

Pullaiah, T. (1997). Flora of Andhra Pradesh. Monocotyledons scientific publishers, 5A, New Pali Roads, Jodhpur, India. pp. 3.

Ram, A.; Das, M. and Ghosh, B. (2003). Curcumin attenuates allergin induced airway hyper responsiveness in sensitized guinea pigs. Biological and Pharmaceutical Bulletin, 26:1021-1024.

Ramachandraiah, O.S.; Azeemoddin, G. and Krishnama, C.(1998). Turmeric leaf oil, a new essential oil for perfume industry. Indian Perfumer, 42(11):124-127

Rasheed, N.M.A.; Srividya G.S. and Nagaiah, K. (2017). HPTLC method development and quantification of curcumin content in different extracts of rhizomes of Curcuma longa L. Annals of Phytomedicine, 6(2):74-81. doi:10.21276/ap.2017.6.2.6.

Ratnam, K.V. and Raju, R.R.V., 2005 (2005).Folk medicine used for common women ailments by adivasis in the Eastern Ghats of Andhra Pradesh. Indian journal of Traditional Knowledge, 4(3):267-270.

Raul, S.K.; Padhy, G.K.; Charly, J.P. and Kumar, V.K.(2012). An in-vitro evaluation of the anthelmintic activity of rhizome extracts of Zingiber officinalis, Zingiber zerumbet and Curcuma longa, a comparative study. Journal of Pharmacy Research, 5(7):38133814.

Reanmongkol, W.; Subhadhriraskul, S.; Khaisombat, N.; Fuengnawakit, P.; Jantasila, S. and Khamjun, A.(2006). Investigation the antinociceptive, antipyretic and anti-inflammatory activities of Curcuma aeruginosa Roxb. extracts in experimental animals. Journal of food Science and Technology, 28(5):999-1008.

Revarkar, G.D. and Sen, D.P.(1975). Antioxidant activity of curcumin and related compounds. Journal of the Oil Technology Association, 25(15):1210-1214.

Rithaporn, T.; Monga, M. and Rajasekharan, M.(2003). Curcumin a potential vaginal contraceptive. Contraception, 68(3):219-225.

Ross, I.A.(1999). Medicinal Plants of the world: Chemical constituents, traditional and modern medicinal uses, Human press, New Jersey. pp. $139-153$.

Rubalakshmi, G. and Karmegam, N. (2011). Antioxidant and anticancer activities of an endemic medicinal plant Curcuma neilgherrensis Wt. (Zingiberaceae). Journal of Agriculture and Food Chemistry, 1(1):27-36.

Saha, D. and Paul, S. (2012). Study of antidiarrhoeal activity of two Bangladeshi medicinal plants in castrol-oil induced diarrhoea. Research Journal of Pharmacy and Technology, 5(6):1-2

Sasaki, R.; Nishimura, N.; Hoghino, H.; Isa, Y.; Kadowaki, M.; Ichi, T.; Tanaka, A.; Nishiumi, Shin.; Fukuda, I.; Ashida, H.; Horio, F. and Tsuda, T.(2007). Cyanidin 3 - glucoside ameliorates hyper glycemia and insulin sensitivity due to down regulation of retinol binding protein and expression in diabetes mice. Biochemical Pharmacology, 74(11):1619-1627.

Sasikumar,B. (2005). Genetic resources of Curcuma: diversity characterization and utilization. Plant Genetic Resources, 3(2): 230-251.

Sharma, M.C. and Joshi, C.(2004). Plants used in skin diseases of animals. Natural Product Radiance, 3(4):293-299.

Shyam, P.M.; Ramachandran, A.P.; Chandola, H.; Harisha, C.R. and Shukla, V.J. (2012). Pharmacognostical and phytochemical studies of Curcuma neilgherrensis (Wight) leaf-A folklore medicine. Ayurveda, 33(2):284-288. 
Si, D.; Wang, Y.; Zhou, Y.; Guo, Y.; Wang, J.; Zhou, H.; Li, Z. and Fawcett, J.P. (2009). Mechanisms of CYPZC9 inhibition by flavones and flavones. Drug Metabolism and Disposition, 37(3):629-634.

Singh, R.; Mehta, A.; Mehta, P. and Shukla, K.(2011). Anthelmintic activity of rhizome extracts of Curcuma longa and Zingiber officinale (Zingiberaceae). International Journal of Pharmacy and Pharmaceutical Sciences, 3(2):236-237.

Singh, R.P. and Jain, D.A.(2011). Evaluation of antimicrobial activity of volatile oil and total curcuminoids extracted from turmeric. International Journal of Chem.Tech. Research, 3(3):1172-1178.

Sudharshan, S.J.; Kekuda, T.R.P. and Sujatha, M.L.(2010). Anti-inflammatory activity of Curcuma aromatic Salisb and Coscinium fenestratum Colebr: A Comparative Study. 3(1):24-25.

Suryanarayana, P.; Krishnaswamy, K. and Reddy, G.B.(2003). Effect of curcumin on galactose induced cataractogenesis in rats. Molecular Vision, 9(33):223-230

Syiem, D.; Monsang, W. and Sharma, R.(2010). Hypoglycemic and antihyperglycemic activity of Curcuma amada Roxb. in normal and alloxan-induced diabetic mice. Pharmacologyonline, 3:364-372.

Tag, H.; Das, A.K. and Loyi, H.(2007). Anti-inflammatory plants used by the Khami tribe of Lohit district in eastern Arunachal Pradesh, India. Natural Product Radiance,6(4):334-340.

Toda, S.; Miyase, T.; Arichi, H.; Tanizawa, H. and Takino, Y.(1985). Natural antioxidants III: Antioxidative components isolated from rhizomes of Curcuma longa L. Chemical Pharmaceutical Bulletin, 33(4):1725-1728
Tonari, K.; Katsui, Mitsui, and Moto, K.Y. (2002). Caffeic acid weakens the aestrogenic activity. Journal of Oleo Science, 5(1):4271.

Varghese, J.(1999). Curcuminoids, the magic dye of $C$. longa L. rhizome. Indian Spices, 36(5):19-26.

Velayudhan, K.C.; Muralidharan, V.K.; Amalraj, V.A.; Gautam, P.L.; Mandal, S. and Kumar, D. (1999).Curcuma Genetic Resources. National Bureau of Plant Genetic Resources, Regional Station, Trichur, Kerala.

Watt, G.(1872). A Dictionary of the Economic Products of India. Vol. II, New Delhi: Today and Tomorrows Pub.

Wilson, B.; Abraham, G.; Manju, V.S.; Mathew, M.; Vimala, B.; Sundaresan, S. and Nambisan, B.(2005). Antimicrobial activity of Curcuma zedoaria and Curcuma malabarica tubers. Journal of Ethnopharmocology, 99(1):147-151.

Yasodamma, N. and Chaithra, D. (2016).Effect of Curcuma Neilgherrensis Wt. rhizome crude extracts on analgesic and arthritis induced rats. World Journal of Pharmacy and Pharmaceutical Sciences, 5(4):1054-1077.

Yasodamma, N.; Chaithra, D. and Alekhya, C.(2014).Qualitative analysis of phenols, flavonoids and anthocyanidins ofCurcuma neilgherrensis Wt. A medicinal plant from seshachalam hills. Indo American Journal of Pharmaceutical Research, 4(9):3618-3629.

Yasodamma, N.; Chaithra, D. and Alekhya, C. (2013). Antibacterial activity of Curcuma neilgherrensis Wt. from seshachalam hills.International Journal of Pharmacy and Pharmaceutical Sciences, 5(3):571-576. 